\title{
Spatial Distribution of Colored Dissolved Organic Matter in the Western Arctic Ocean
}

\author{
Xiaoxia Cai ${ }^{1}$, Yanpei Zhuang ${ }^{2}$, Hongliang $\mathrm{Li}^{1}{ }^{1}$, Jing $\mathrm{Xu}^{3}{ }^{3}$, Haiyan Jin ${ }^{1, *}$ and Jianfang Chen ${ }^{1}$ \\ 1 Key Laboratory of Marine Ecosystem Dynamics, Second Institute of Oceanography, Ministry of Natural \\ Resources, Hangzhou 310012, China; Caixx@sio.org.cn (X.C.); lihongliang@sio.org.cn (H.L.); \\ jfchen@sio.org.cn (J.C.) \\ 2 Polar and Marine Research Institute, Jimei University, Xiamen 361000, China; Zhungyp@sio.org.cn \\ 3 State Key Laboratory of Marine Environmental Science, Xiamen University, Xiamen 361000, China; \\ xj823@xmu.edu.cn \\ * Correspondence: jinhaiyan@sio.org.cn
}

Citation: Cai, X.; Zhuang, Y.; Li, H.; Xu, J.; Jin, H.; Chen, J. Spatial

Distribution of Colored Dissolved Organic Matter in the Western Arctic Ocean. J. Mar. Sci. Eng. 2022, 10, 352. https://doi.org/10.3390/jmse10030352

Academic Editor: George Kontakiotis

Received: 8 November 2021

Accepted: 9 December 2021

Published: 2 March 2022

Publisher's Note: MDPI stays neutral with regard to jurisdictional claims in published maps and institutional affiliations.

Copyright: (c) 2022 by the authors. Licensee MDPI, Basel, Switzerland. This article is an open access article distributed under the terms and conditions of the Creative Commons Attribution (CC BY) license (https:// creativecommons.org/licenses/by/ $4.0 /)$

\begin{abstract}
Optical properties of colored dissolved organic matter (CDOM) were investigated along a latitudinal transect $\left(67^{\circ}-77^{\circ} \mathrm{N}\right)$ in upper water $(<80 \mathrm{~m}$ depth) of the western Arctic Ocean. The absorption coefficient at $280 \mathrm{~nm}$ was $0.48-1.25 \mathrm{~m}^{-1}$, with the average for the oligotrophic basin area $\left(1.04 \pm 0.08 \mathrm{~m}^{-1}\right)$ being slightly higher than that of the productive shelf area $\left(0.95 \pm 0.16 \mathrm{~m}^{-1}\right)$, implying a decoupling effect between CDOM concentration and biological productivity in the western Arctic Ocean. The spectral slope coefficient $S_{270-350}$ was negatively correlated with salinity, indicating that DOM molecular weight increases with salinity, and may be affected by melt-water input. Four fluorescent components were identified by excitation emission matrices elaborated by parallel factor analysis, including three humic-like (C1, C3, and C4) components and one protein-like (C2) component. Significant increases in concentrations of terrestrially derived humic-like C3 and C4 components with salinity were observed in the basin, mainly controlled by the physical mixing of surface fresh water and subsurface inflowing Pacific Ocean water. Terrestrial material carried by Pacific inflow is thus an important factor affecting the distribution of CDOM fluorescence components. The C3 and C4 fluorescence components may be useful as tracers of Pacific water in the western Arctic Ocean.
\end{abstract}

Keywords: colored DOM; marine carbon cycle; Arctic Ocean; ice melt; Pacific water inflow

\section{Introduction}

Marine dissolved organic matter (DOM) constitutes one of the largest reduced carbon reservoirs on Earth and is actively involved in the carbon cycle, marine food webs, and climatic effects [1]. Colored DOM (CDOM) is the chromophoric fraction of DOM with light-absorbing properties in the oceans [2]. Sources of marine CDOM include terrestrial input, in situ oceanic production, and sediments [3-5], with its removal occurring mainly through photodegradation and microbial degradation [3]. Production and removal of CDOM thus affect light attenuation and biological metabolism in the oceans.

Rapid sea-ice loss has increased freshwater storage in the western Arctic Ocean [6], while the intensification of the Beaufort Gyre led to additional freshwater accumulation in the region [7]. Besides, Pacific water inflow through the Bering Strait is increasing and warming [8], and this inflow water is stored below the sea surface once it enters the western Arctic basins [9]. Continuous melting of Arctic sea ice has triggered major changes in the light and nutrient status of the Arctic Ocean [10,11], biogenic gas emissions [12], terrestrial material delivery [13], primary production [14], and phytoplankton composition [15]. Carbon dioxide uptake and organic matter production in Arctic shelf waters appears to have increased as a result [16], but not in the basin waters [17], which is due to the nutrient limitations in the region [11]. 
Such changes in physical and biogeochemical processes (e.g., expansion of Pacific water inflow, terrestrial input, and microbial degradation) are likely to alter the biogeographic distribution of CDOM. Previous reports have indicated the considerable temporospatial variability of CDOM concentrations in response to changes in hydrographic and sea-ice conditions [18,19], which influence phytoplankton bloom [18] and photodegradation of humic material [19]. The bioavailability of DOM, which supports microbial food webs, also exhibits considerable pan-Arctic variability, with high labile DOM observed in productive shelves (e.g., Chukchi and Barents Seas) and low labile DOM in oligotrophic shelves (e.g., Beaufort and East Siberian Seas) [20]. Considering its complexity in this poorly-sampled region, an understanding of CDOM distribution patterns and their relationship to environmental changes is important in elucidating changes in the carbon cycle and ecosystem of the Arctic Ocean.

Optical properties such as absorption and fluorescence have been used to assess the concentration and composition of DOM [21-24]. More detailed characterization of fluorescent components of CDOM is provided by excitation emission matrix (EEM) and parallel factor analysis (PARAFAC) modeling [25,26]. Here, CDOM absorption and fluorescence spectroscopy were applied to samples collected along a transect across the Chukchi shelf and Arctic Ocean basin (Figure 1$)$, to obtain the optical properties $\left(a_{\mathrm{CDOM}}, S_{270-350}\right.$, fluorescent components) of CDOM in the water column. The shelf-basin difference in CDOM concentration was considered in exploring CDOM distribution patterns under different biological-production regimes. We discuss the conservative/non-conservative behavior of CDOM, and its relationship with ice melting and Pacific inflow in the western Arctic Ocean.

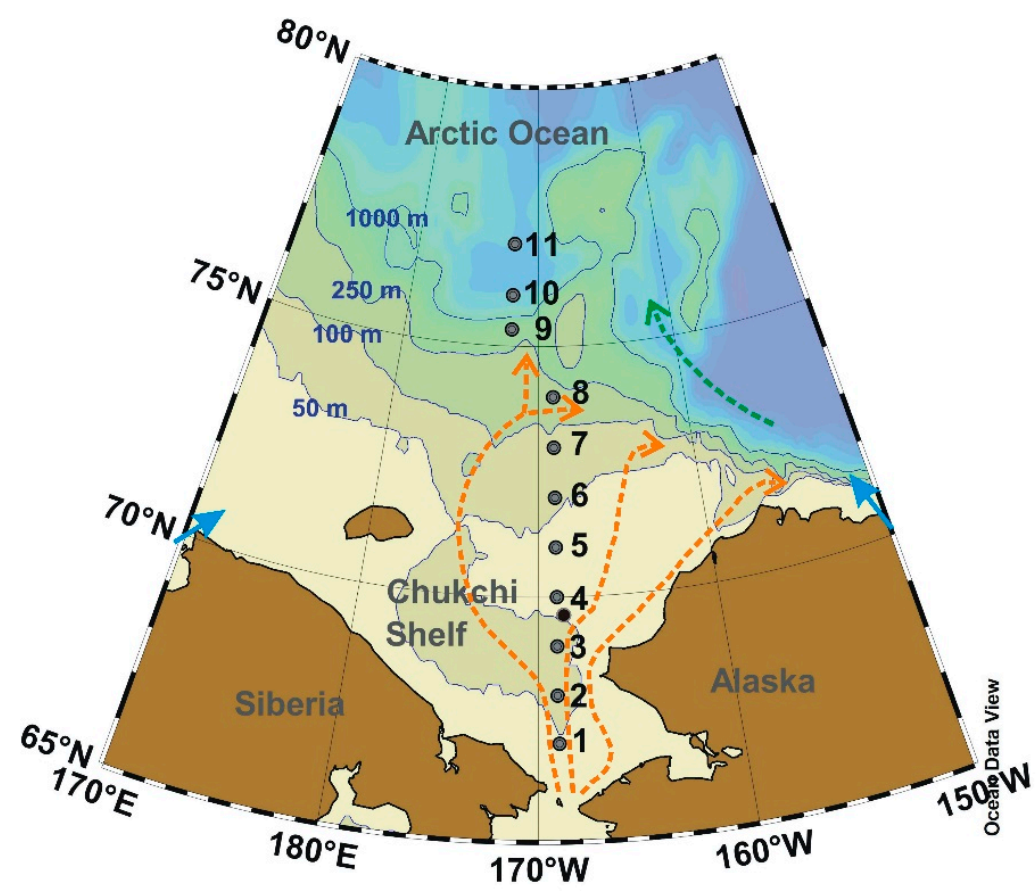

Figure 1. Location of sampling stations along a $67^{\circ}-77^{\circ} \mathrm{N}$ transect at $\sim 170^{\circ} \mathrm{W}$ in the western Arctic Ocean. Blue lines indicate 50, 100, 250 and $1000 \mathrm{~m}$ isobaths. Red arrows indicate the various pathways of the Pacific inflow water. Green arrow indicates Beaufort Gyre. Blue arrows indicate riverine freshwater input.

\section{Materials and Methods}

\subsection{Study Sites and Sampling}

Water samples were collected from the upper water column (sampling depths $<80 \mathrm{~m}$ ) at 11 stations along a $67^{\circ}-77^{\circ} \mathrm{N}$ transect in the shelf (water depths $<200 \mathrm{~m}$ ) and basin (water depths $>200 \mathrm{~m}$ ) areas during a summer cruise of the RV Xuelong in the open-water season, 26-30 August 2010 (Figure 1). Samples for CDOM analysis were collected using a Pall 
in-line glass-fiber (GF/F) filter pre-prepared by soaking in $2 \mathrm{~mol} \cdot \mathrm{L}^{-1} \mathrm{HCl}$, washing with Milli-Q water, and combustion at $500{ }^{\circ} \mathrm{C}$ for $5 \mathrm{~h}$. Samples were stored at $-4{ }^{\circ} \mathrm{C}$ pending analysis. The hydrological parameters (i.e., salinity and temperature) and chlorophyll fluorescence were recorded using a pre-calibrated CTD profiler (SBE 911plus, Sea-bird, Bellevue, WA, USA).

Pacific water flow across the Chukchi Sea along three principal pathways (Figure 1). In addition, Pacific water subduct into subsurface layer once it enters the western Arctic Ocean basin. Pacific summer water is located beneath the polar mixed layer, underlie is Pacific winter water. Due to the influence of ice formation and brine reject in wintertime, Pacific winter water has the characteristics of saline and relatively dense. Pacific summer and winter waters distribute in subsurface (50-200 m) of Arctic Ocean basin, consist of the Pacific-origin components of the halocline water.

\subsection{Absorption Spectroscopy Analysis}

CDOM absorption spectra were acquired using a 2300 dual-beam UV-Visible spectrophotometer (Techcomp, Beijing, China) with a $10 \mathrm{~cm}$ quartz cell, a scanning range of $240-800 \mathrm{~nm}$, and spectral resolution of $1 \mathrm{~nm}$. Milli-Q water was used as the blank. Absorbance (A) was converted to absorption coefficient $\left(\mathrm{m}^{-1}\right)$ using the expression $a_{\mathrm{CDOM}(\lambda)}=2.303 \mathrm{~A}_{(\lambda)} / \mathrm{L}$, where $\lambda$ is wavelength and $\mathrm{L}$ is cuvette length. The absorption coefficient at $280 \mathrm{~nm}, a_{\mathrm{CDOM}}$ (280), was used as a proxy for CDOM concentration. A non-linear regression method was employed to estimate the spectral slope coefficient $\left(S_{270-350}\right)$ over a wavelength range of 270-350 nm using the equation of Markager and Vincent [27]. $S_{270-350}$ represents the exponential ratio of the spectral slope, which is negatively correlated with DOM molecular weight [27].

\subsection{EEM and PARAFAC Modeling}

EEM fluorescence spectra were acquired with a Cary Eclipse fluorescence spectrophotometer (Varian, Australia) equipped with a $150 \mathrm{~W}$ Xe arc lamp. EEMs were obtained by scanning a series of emission spectra over $230-600 \mathrm{~nm}$ at $2 \mathrm{~nm}$ intervals with excitation at $200-450 \mathrm{~nm}$ at $5 \mathrm{~nm}$ intervals. The EEM for each sample was Raman-calibrated and a Raman-normalized Milli-Q water EEM (scanned the same day) was subtracted.

EEM spectra were modeled using PARAFAC analysis with MATLAB 7.5 and the DOM Fluor toolbox [28]. Split-half validation was applied to determine the number of components. PARAFAC analysis decomposed the EEMs into individual components, yielding a concentration score for each component in every sample. Fluorescence intensity of each component was represented by Fmax (in Raman units, RU) [24], calculated by multiplying the concentration score by the maximum excitation and emission loadings for each component.

\section{Results}

\subsection{Variability of Environmental Factors and CDOM Absorption Properties}

In summer, high-temperature water $\left(>4{ }^{\circ} \mathrm{C}\right.$ ) occupies the shelf area (water depths $<200 \mathrm{~m}$ ) of the western Arctic Ocean, with temperatures reaching up to $7.9^{\circ} \mathrm{C}$ (Figure 2a). The basin area (water depths $>200 \mathrm{~m}$ ) is occupied by cold water masses $\left(<0{ }^{\circ} \mathrm{C}\right)$, forming a strong temperature gradient with warmer water on the continental shelf. The salinity distribution indicates there was a low-salinity area $(<28)$ on the surface $(<20 \mathrm{~m} \mathrm{depth})$ of the basin, due to accumulation of freshwater (Figure 2b). Chlorophyll fluorescence highlights spatial differences between shelf and basin areas (Figure 2), with the former being occupied by relatively high-temperature and saline water with relatively high chlorophyll concentrations, and the latter occupied by lower-temperature and fresher water with lower chlorophyll levels. The penetration of warm Pacific water and variability of freshwater input appears to be the major contributor of the environmental factor change.

Along the transect, $a_{\mathrm{CDOM}}(280)$ was in the range of $0.48-1.25 \mathrm{~m}^{-1}$ (Mean $\pm \mathrm{SD}$ $0.95 \pm 0.16 \mathrm{~m}^{-1}$; Figure 2d), with the average value for the shelf area $\left(0.90 \pm 0.17 \mathrm{~m}^{-1}\right)$ 
being slightly lower than that of the basin area $\left(1.04 \pm 0.08 \mathrm{~m}^{-1}\right) . S_{270-350}$ values were in the range of $0.026-0.037 \mathrm{~nm}^{-1}$ (average $0.030 \pm 0.003 \mathrm{~nm}^{-1}$; Figure 2e), with a high-value area $\left(>0.034 \mathrm{~nm}^{-1}\right)$ at the basin surface. The vertical variation in $S_{270-350}$ was more pronounced than the latitudinal variation in $a_{\mathrm{CDOM}}$ (280) (Figure 2e).
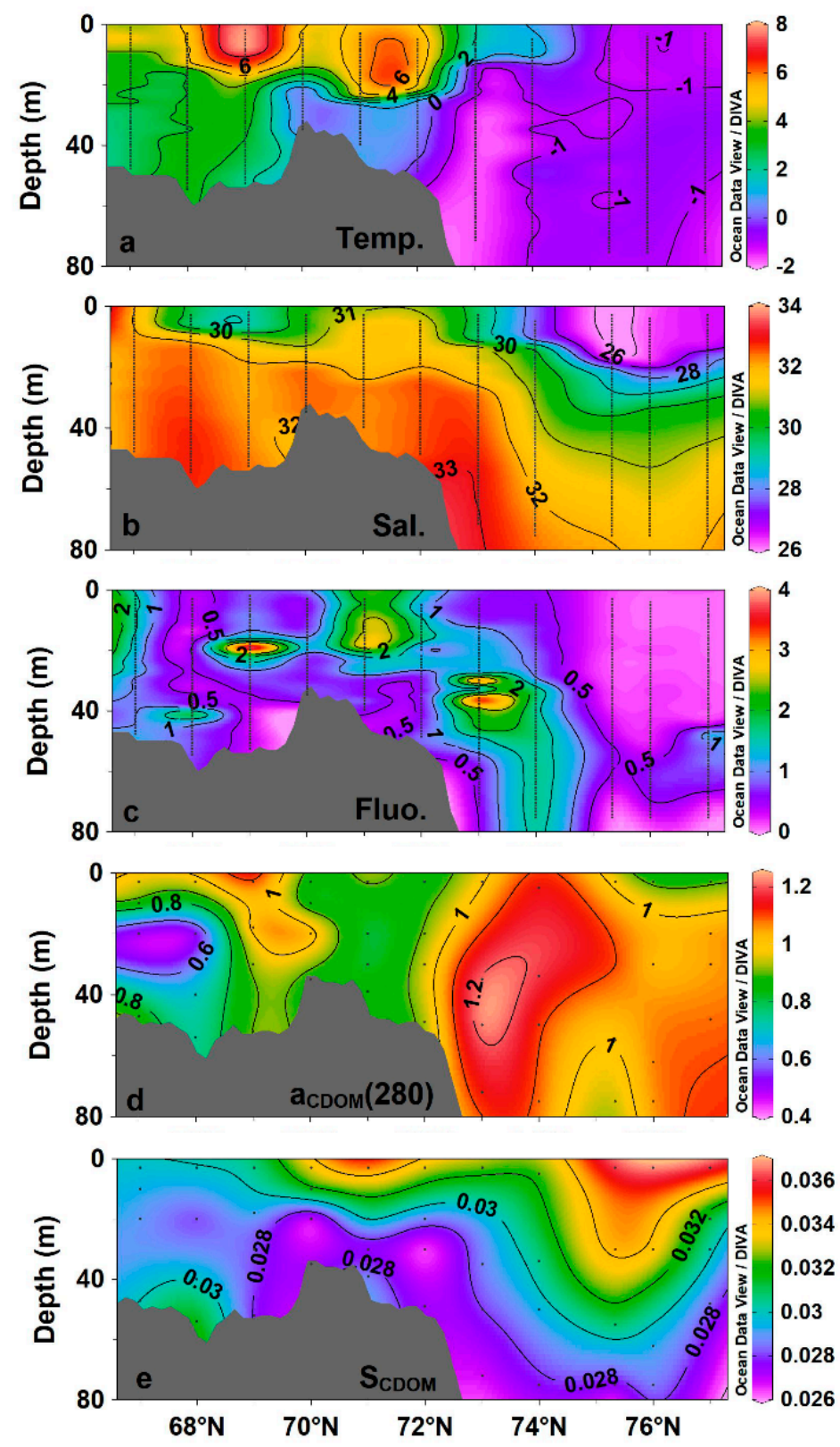

Figure 2. Distribution of environmental factors and CDOM absorption properties along the $67^{\circ}-77^{\circ} \mathrm{N}$ transect in the western Arctic Ocean. (a) Temperature $\left({ }^{\circ} \mathrm{C}\right) ;(\mathbf{b})$ salinity (PSU); (c) chlorophyll fluorescence; (d) $a_{\mathrm{CDOM}}(280)\left(\mathrm{m}^{-1}\right)$; (e) $S_{270-350}\left(\mathrm{~nm}^{-1}\right)$. Black dots indicate data points.

\subsection{Fluorescent Component Characteristics}

Four fluorescent components were identified through EEM-PARAFAC modeling, i.e., three humic-like ( $\mathrm{C} 1, \mathrm{C} 3$, and $\mathrm{C} 4)$ components and one protein-like (C2) component (Figure 3). C1 had excitation maxima at 250 and $295 \mathrm{~nm}$ and emission maxima at $398 \mathrm{~nm}$, spanning the EEM regions of humic-like peaks A and M (290-312/370-420 nm), whereas $\mathrm{C} 2$ had excitation/emission maxima at $270 / 315 \mathrm{~nm}$, resembling a combination of tyrosinelike peak B (275/300 nm) and tryptophan-like peak T [29]. C3 had excitation maxima at 260 and $375 \mathrm{~nm}$, and emission maxima at $474 \mathrm{~nm}$. C4 had excitation maxima at 250 and 
$345 \mathrm{~nm}$, and emission maxima at $418 \mathrm{~nm}$. Both of these are similar to the traditionally defined humic-like fluorescence peaks A (260/380-460 nm) and C (320-360/420-480 nm) [29], respectively.
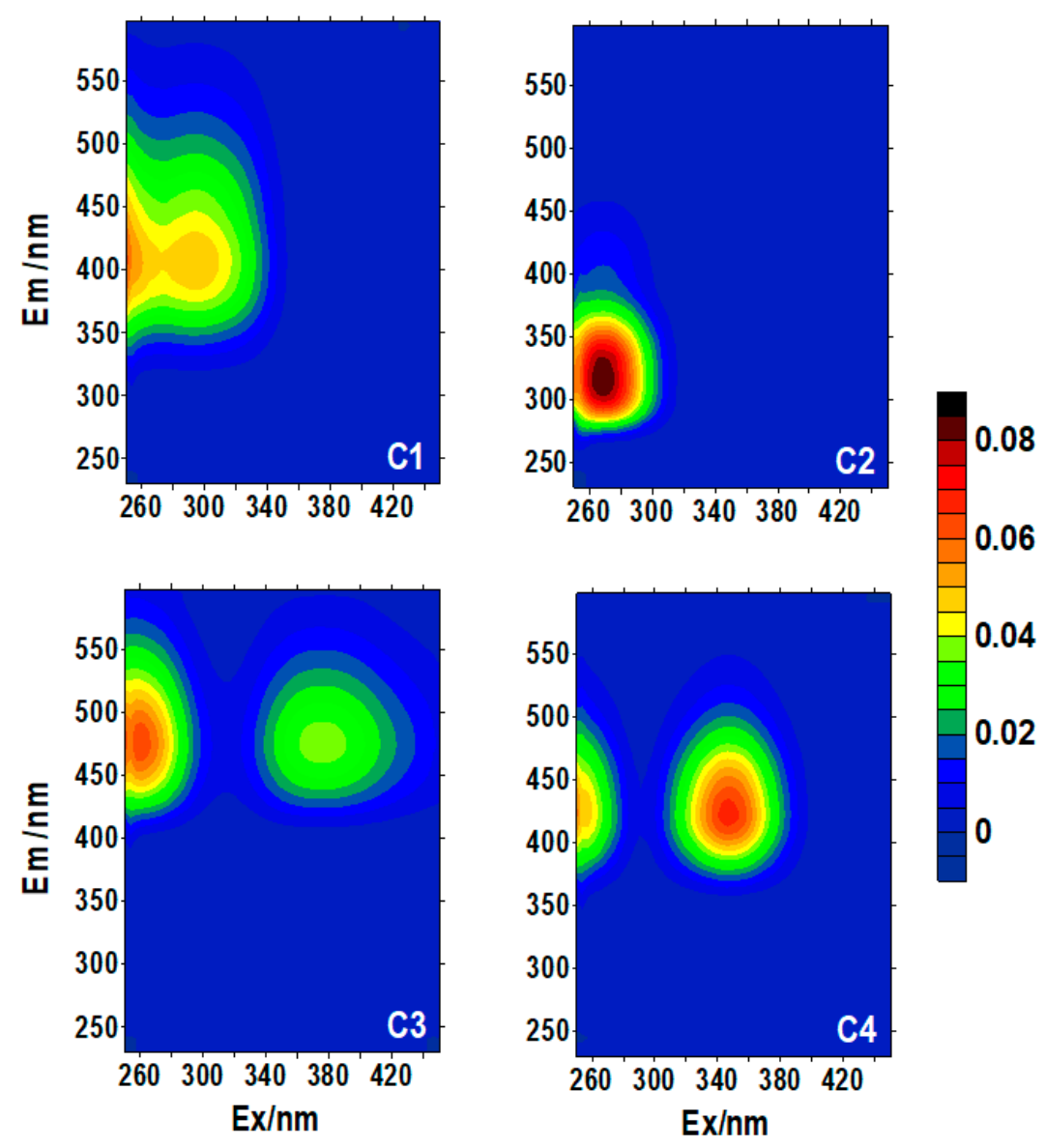

Figure 3. Four fluorescent components (C1-C4) identified using EEM-PARAFAC for upper water (sampling depth $<80 \mathrm{~m}$ ) of the western Arctic Ocean.

A correlation analysis was undertaken for different fluorescent components to investigate their internal relationships (Figure 4). Fluorescence components C3 and C4 were strongly correlated $\left(\mathrm{R}^{2}=0.90 ; p<0.001\right)$, indicating similar sources and/or controlling factors (Figure $4 \mathrm{a})$. Component $\mathrm{C} 1$ was moderately correlated with $\mathrm{C} 4\left(\mathrm{R}^{2}=0.63 ; p<0.001\right)$ but with deviations (Figure $4 \mathrm{~b}$ ), with $\mathrm{C} 1$ being derived mainly from both marine and terrestrial humic components, as indicated by its EEM regions, whereas C3 and C4 are mainly of terrestrial origin. C2 was not correlated with either C1 or C4 (not shown), suggesting distinct temporospatial behavior.

\subsection{Variability in CDOM Fluorescent Components}

Fluorescent component $\mathrm{C} 1$ had the highest fluorescence intensity of $0.010-0.026$ R.U. (average $0.019 \pm 0.005$ R.U.; Figure 5a), with high-intensity areas (>0.02 R.U.) on the surface of the southern shelf $\left(67^{\circ}-69^{\circ} \mathrm{N}\right)$ and in the subsurface in the basin area. Fluorescent component C2 had intensities of 0.004-0.025 R.U. (average $0.014 \pm 0.005$ R.U.), with higher intensities being distributed mainly at the surface of the basin area (Figure 5b). C3 and C4 had similar intensity distributions, with high-intensity areas ( $>0.01$ R.U.) being distributed mainly in subsurface water (Figure 5c,d). 

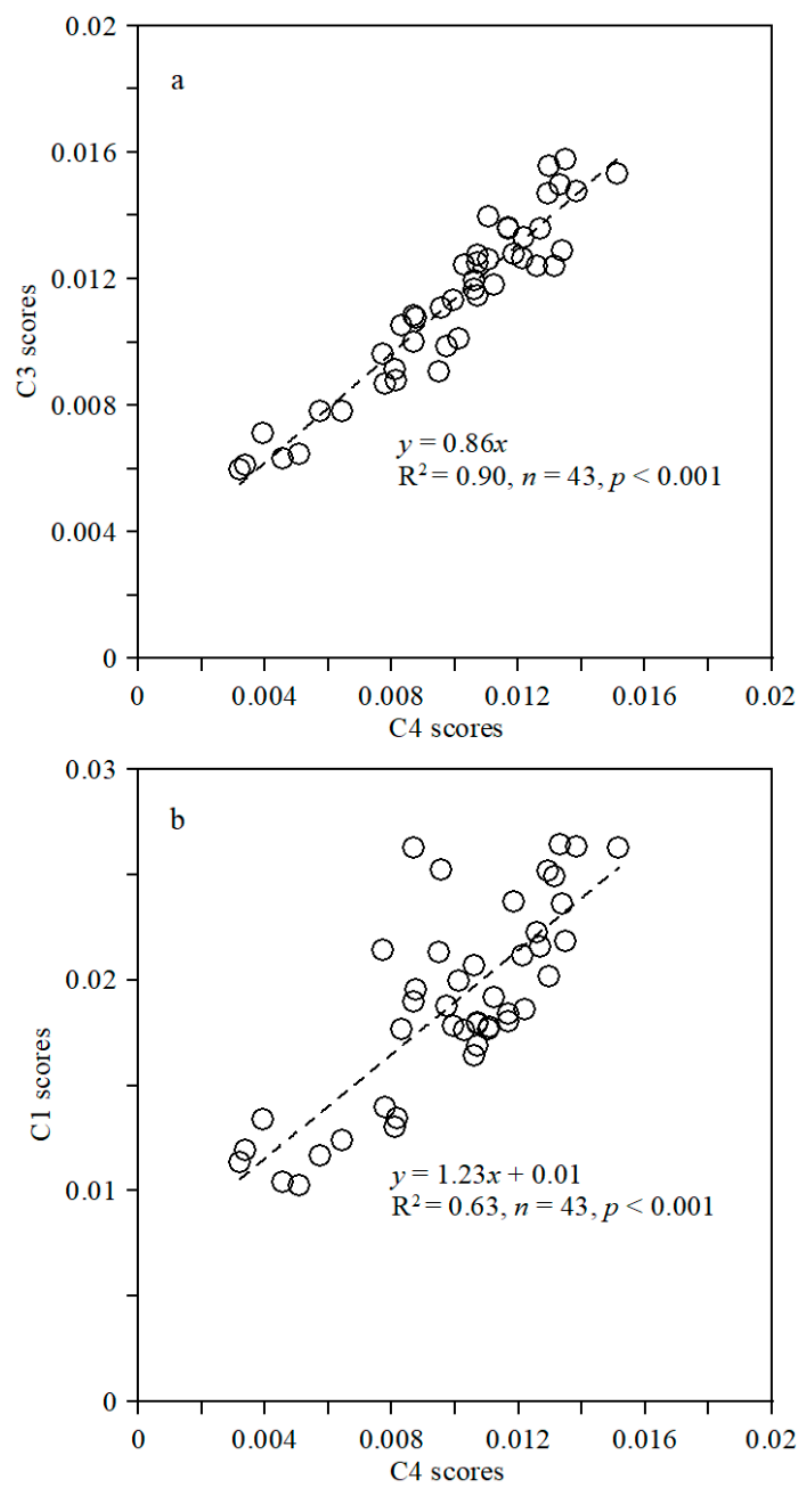

Figure 4. Correlation analysis of CDOM fluorescent components: (a) C4 and C1; (b) C4 and C3.
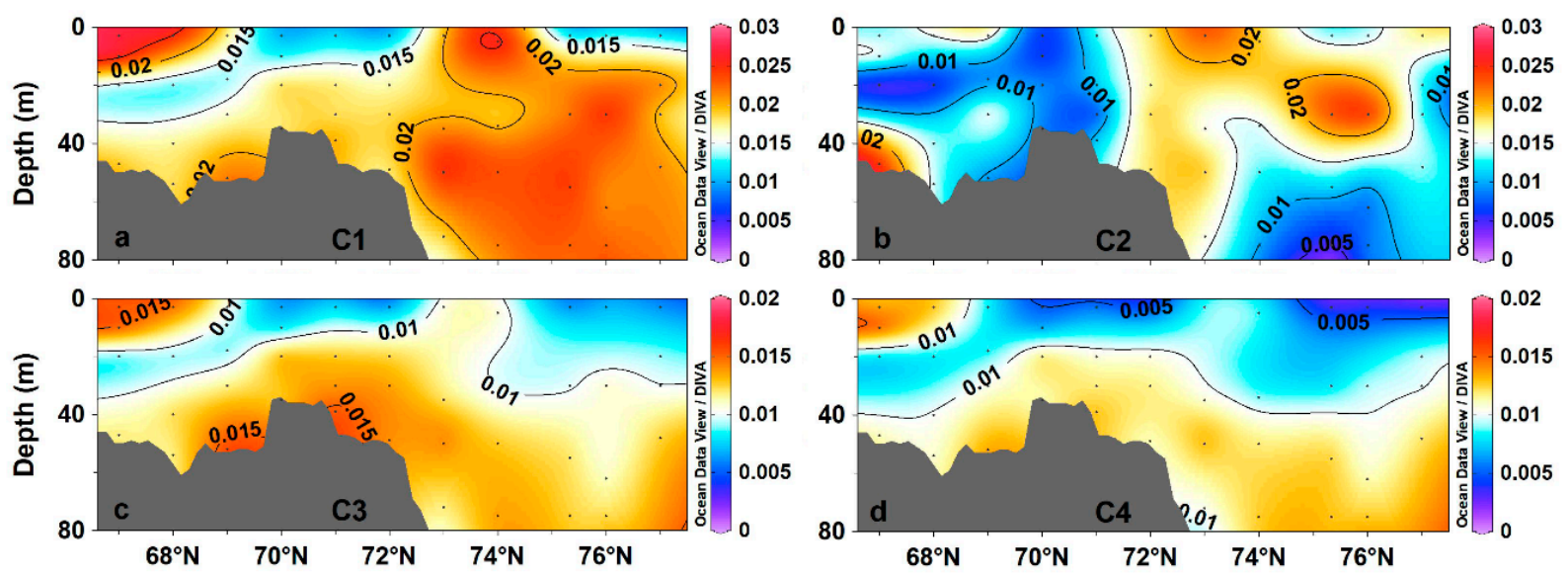

Figure 5. Distribution of CDOM fluorescent components along the transect $\left(67^{\circ}-77^{\circ} \mathrm{N}\right)$ in the western Arctic Ocean: (a) C1; (b) C2; (c) C3; and (d) C4. 
The intensity distribution of component C1, contributed by terrestrial humic-like peak A and oceanic-source humic-like peak M, is clearly affected by the distribution of Pacific water and its biological activity. The $\mathrm{C} 2$ fluorescence intensity was higher in the basin area than on the shelf, consistent with the distribution of $a_{\mathrm{CDOM}}(280)$, and indicating that it may not be affected by primary production. Fluorescent components $C 3$ and $C 4$ originate mainly from terrestrial humic-like peaks A and C, with their distributions being particularly affected by Pacific water inflow, which is stored in the basin subsurface layer after entering the Arctic Ocean basin.

\section{Discussion}

\subsection{Shelf-Basin Difference in CDOM Concentration}

The magnitudes of biogeochemical variables are usually greater in shelf than basin areas of the western Arctic Ocean, particularly for nutrient concentration [11], primary production [14], and particulate organic carbon concentrations [30], which are associated with productive and oligotrophic systems. However, CDOM absorption coefficient in the shelf area were significant different from and slightly lower than in the basin (Figure 6), which is inconsistent with the high shelf primary productivity. The significance of the difference was analyzed by the non-parametric K-S test and independent $t$-test based on IBM SPSS 20.0. Previous studies have indicated that biological production has little influence on CDOM distribution on the Chukchi Shelf [31], and that dissolved organic carbon (DOC) concentrations in shelf and basin surface waters are not significantly different in the western Arctic Ocean [32]; DOC and CDOM concentrations are usually strongly correlated [33]. Geographical variations in overall CDOM concentration are thus decoupled from internal biological activity with respect to other biogeochemical parameters involved in productive and low-production systems.

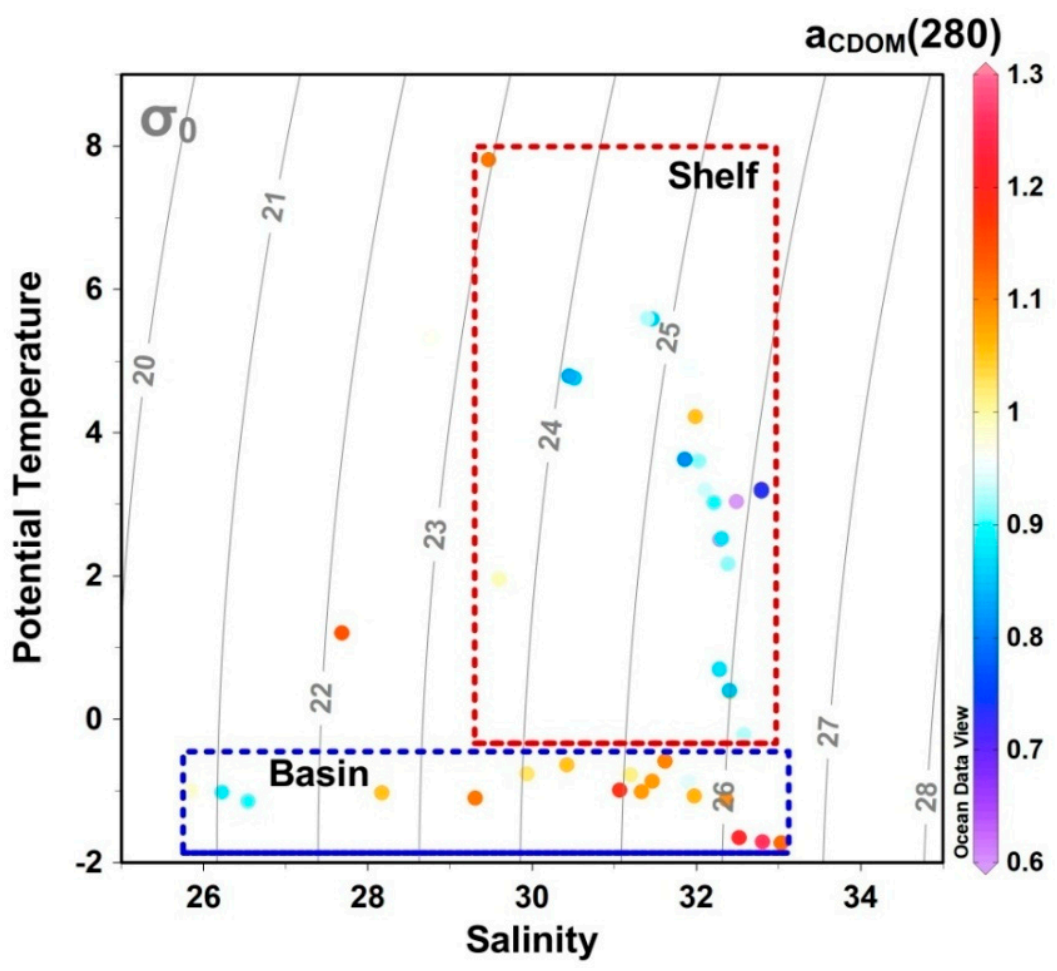

Figure 6. Temperature-salinity- $a_{\mathrm{CDOM}}$ (280) diagrams for the shelf and basin areas of the western Arctic Ocean. Gray curves represent contours of potential density, $\sigma\left(\mathrm{kgm}^{-3}\right)$. The CDOM absorption coefficient $\left(a_{\mathrm{CDOM}}(280)\right)$ in the shelf area shown significant different from that in the basin.

The shelf area of the western Arctic Ocean is one of the most productive ocean areas globally [34], with a predominance of diatoms in the phytoplankton community [35]. DOM 
sources for the shelf area include inputs from Pacific inflow and sediments, and internal production by biological activity [36]. However, due to the low pelagic consumption limited by low temperatures of the Arctic shelf, the diatom biomass reaches mainly benthic communities [37] and, compared with low-latitude waters, CDOM concentrations in the western Arctic Ocean may not be intrinsically related to overall biological production [38]. Rather, CDOM variations may be related to internal production by a microbial carbon pump that is more active in the basin area than on the shelf. Microbial-origin CDOM fluorescent components are abundant in basin water [19], with previous studies having found a significant increase in levels of the smallest phytoplankton (picophytoplankton) in the basin area in response to environmental changes [39,40].

\subsection{Effects of Ice Melting and Pacific Inflow on CDOM Fluorescence}

The conservative and non-conservative behaviors of CDOM were evaluated by analysis of correlations between $a_{\mathrm{CDOM}}(280), \mathrm{S}_{\mathrm{CDOM}}$, fluorescence and salinity (Figure 7). The CDOM absorption coefficient in the basin area increased slightly with salinity, but with no significant correlation ( $p>0.05$; Figure $7 \mathrm{a}$ ). The CDOM concentration is affected by the accumulation of freshwater in the basin area, through dilution of low-CDOM melt water. A previous study found a clear reduction in DOC concentration attributable to mixing of low-DOC melt water and high-DOC riverine water [41]. $\mathrm{S}_{\mathrm{CDOM}}$ was negatively correlated with salinity $\left(R^{2}=0.85 ; p<0.001\right.$; Figure $\left.7 b\right)$, indicating that the DOM molecular weight increases with salinity, and implying that the major factor controlling the distribution of DOM molecular weight is the mixing of water masses. Low-molecular-weight DOM $\left(\mathrm{M}_{\mathrm{n}}<350 \mathrm{Da}\right)$ tends to be accumulated in surface water of the Arctic Ocean [42]. Most DOM in both ice and surface water has low molecular weight and is most likely derived from microbial degradation [43].

The concentration of fluorescent component $\mathrm{C} 1$ increased with salinity (Figure 7c), whereas that of $\mathrm{C} 2$ decreased (Figure $7 \mathrm{~d})$, but without significant correlation $(p>0.05)$. The C1 comprises mainly terrestrial humic-like substances with only a partial oceanic origin, and its distribution is affected by both physical mixing and local production. The protein-like C2 may be derived from autochthonous CDOM of melt water, which is more abundant in surface water and declines with increasing salinity. A prevalence of proteinlike substances in ice cores has been observed, most likely due to internal production [43]. The CDOM terrestrial signature is thus weak in surface water $(<40 \mathrm{~m}$ depth) of the western Arctic Ocean. The CDOM in surface waters of the Canada Basin is characterized largely by autochthonous production, in contrast to riverine input in the Eurasian Basin [44].

Strongly positive Spearman correlations were observed between the fluorescent components $\mathrm{C} 3$ and $\mathrm{C} 4$ and salinity $(p<0.001$; Figure $7 \mathrm{e}, \mathrm{f})$. Both $\mathrm{C} 3$ and $\mathrm{C} 4$ represent terrestrial humic-like fluorescence, carried mainly by the inflow of Pacific water, entering the subsurface layer of the basin. The Pacific water spread up into the subsurface layer $(>50 \mathrm{~m})$ once it enters the western Arctic basins [9]. The upper and lower bounds of the Pacific water coincide with the 31.0 and 33.5 salinity, and a temperature range from -2 to around $0{ }^{\circ} \mathrm{C}$ [45]. Thus, the spreading of Pacific water is an important contributor to the distribution of fluorescent components. However, the contribution of regeneration cannot be neglected. Early study suggested that the contribution rate of nutrient regeneration to the subsurface nutrient stock can up to $20-30 \%$ [46].

Previous report also found that the subsurface layer of basin area has distinctive enriched terrestrial humic EEM signatures [19]. Fluorescent components C3 and C4 can thus trace the distribution of Pacific water in the western Arctic Ocean. Other studies also indicate the potential to use DOM fluorescence in distinguishing between freshwater contributions of melt water, river water, and Pacific inflow [47]. 

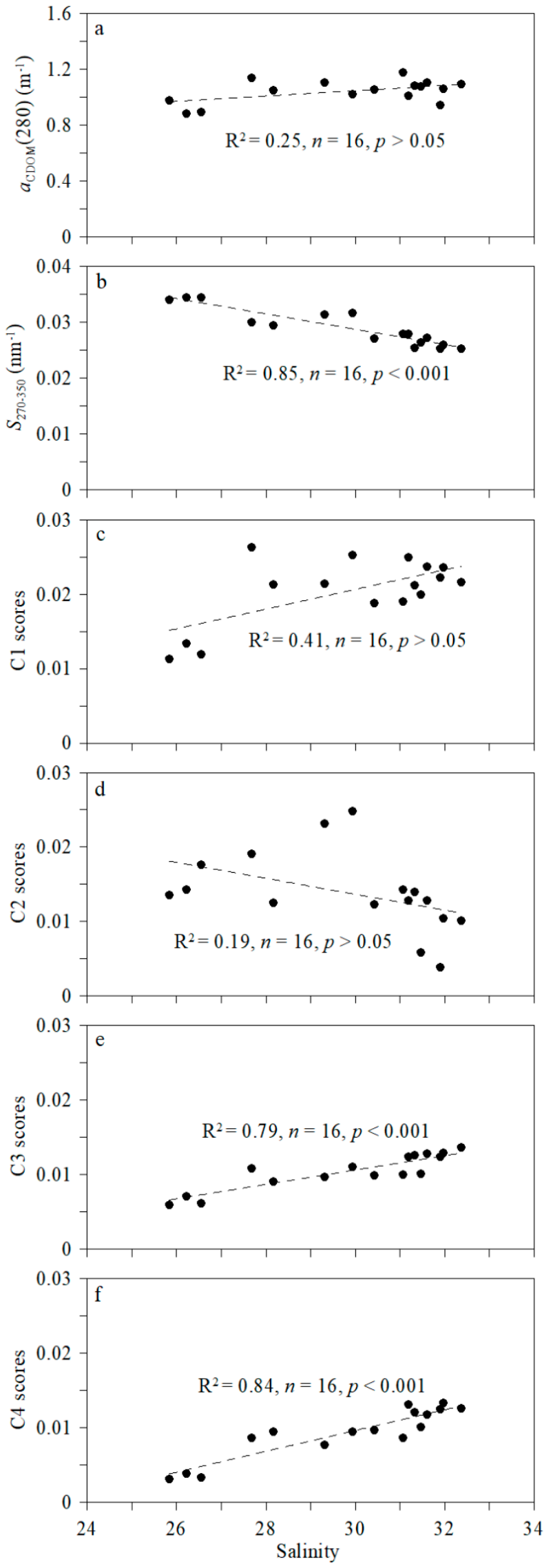

Figure 7. Correlation between salinity and $a_{\mathrm{CDOM}}(280)(\mathbf{a}) ; S_{270-350}(\mathbf{b})$; and fluorescent components $(\mathbf{c}-\mathbf{f})$. Highly significant $(p<0.001)$ and insignificant $(p>0.05)$ correlations are evident. 


\section{Conclusions}

The absorption coefficient, $a_{\mathrm{CDOM}}(280)$, in the productive shelf area is slightly lower than that in the oligotrophic basin area of the western Arctic Ocean, indicating that CDOM concentration is not coupled with overall biological production, but rather may be affected more by microbial production. The spectral slope, $S_{270-350}$, is negatively correlated with salinity, indicating that the DOM molecular weight increases with salinity, and may be affected by low-molecular-weight DOM input by melt water. Freshwater storage has shown significant increase in this area under the spin-up of the Beaufort Gyre [6,7]. Fluorescent component $\mathrm{C} 1$ contains terrestrial and marine humic-like substances that tend to increase in concentration with salinity, but not significantly. Protein-like C2 decreases with increasing salinity, possibly due to the input of melt water. Fluorescent components $\mathrm{C} 3$ and C4 have similar sources and a causal connection. They are represented by terrestrial humic components carried by Pacific water; concentrations of both are positively correlated with salinity and controlled by the physical mixing of freshwater input and Pacific water. Pacific water inflow is a key factor affecting the distribution of CDOM in the western Arctic Ocean. The distributions of the terrestrial humic-like $\mathrm{C} 3$ and $\mathrm{C} 4$ components can be used as tracers of Pacific water.

Author Contributions: Conceptualization, X.C. and H.J.; methodology, X.C.; software, Y.Z. and J.X.; validation, X.C., Y.Z. and H.L.; formal analysis, X.C.; investigation, Y.Z. and H.L.; data curation, X.C.; writing—original draft preparation, X.C.; writing—review and editing, Y.Z., H.L., H.J. and J.C.; visualization, X.C.; supervision, H.J.; project administration, J.C.; funding acquisition, H.J., Y.Z. and J.C. All authors have read and agreed to the published version of the manuscript.

Funding: This research was funded by National Key Research and Development Program of China (2019YFE0120900, and 2019YFE0114800), the National Natural Science Foundation of China (41941013, 41776205, and 41976226).

Institutional Review Board Statement: Not applicable.

Informed Consent Statement: Not applicable.

Acknowledgments: We thank the crew of the icebreaker Xuelong for their assistance during the Chinese Arctic expeditions. The CTD data were provided by the Data-sharing Platform of Polar Science (Available online: http:/ / www.chinare.org.cn:8000/en/index/ (accessed on 1 January 2014)), maintained by the Chinese National Arctic \& Antarctic Data Center.

Conflicts of Interest: The authors declare no conflict of interest.

\section{References}

1. Jiao, N.; Herndl, G.J.; Hansell, D.A.; Benner, R.; Kattner, G.; Wilhelm, S.W.; Kirchman, D.L.; Weinbauer, M.G.; Luo, T.; Chen, F.; et al. Microbial production of recalcitrant dissolved organic matter: Long-term carbon storage in the global ocean. Nat. Rev. Genet. 2010, 8, 593-599. [CrossRef]

2. Benner, R. Chemical Composition and Reactivity. In Biogeochemistry of Marine Dissolved Organic Matter; Hansell, D.A., Carlson, C.A., Eds.; Elsevier: New York, NY, USA, 2002; pp. 59-90.

3. Stedmon, C.A.; Nelson, N.B. The Optical Properties of DOM in the Ocean. In Biogeochemistry of Marine Dissolved Organic Matter; Elsevier BV: Amsterdam, The Netherlands, 2015; pp. 481-508.

4. Chen, M.; Kim, J.-H.; Nam, S.-I.; Niessen, F.; Hong, W.-L.; Kang, M.-H.; Hur, J. Production of fluorescent dissolved organic matter in Arctic Ocean sediments. Sci. Rep. 2016, 6, 39213. [CrossRef]

5. Brogi, S.R.; Charrière, B.; Gonnelli, M.; Vaultier, F.; Sempéré, R.; Vestri, S.; Santinelli, C. Effect of UV and Visible Radiation on Optical Properties of Chromophoric Dissolved Organic Matter Released by Emiliania huxleyi. J. Mar. Sci. Eng. 2020, 8, 888. [CrossRef]

6. Rabe, B.; Karcher, M.; Kauker, F.; Schauer, U.; Toole, J.; Krishfield, R.A.; Pisarev, S.; Kikuchi, T.; Su, J. Arctic Ocean basin liquid freshwater storage trend 1992-2012. Geophys. Res. Lett. 2014, 41, 961-968. [CrossRef]

7. Giles, K.A.; Laxon, S.W.; Ridout, A.L.; Wingham, D.J.; Bacon, S. Western Arctic Ocean freshwater storage increased by wind-driven spin-up of the Beaufort Gyre. Nat. Geosci. 2012, 5, 194-197. [CrossRef]

8. Woodgate, R.; Peralta-Ferriz, C. Warming and Freshening of the Pacific Inflow to the Arctic from 1990-2019 Implying Dramatic Shoaling in Pacific Winter Water Ventilation of the Arctic Water Column. Geophys. Res. Lett. 2021, 48, e2021GL092528. [CrossRef]

9. Timmermans, M.-L.; Marshall, J.; Proshutinsky, A.; Scott, J. Seasonally derived components of the Canada Basin halocline. Geophys. Res. Lett. 2017, 44, 5008-5015. [CrossRef] 
10. Nicolaus, M.; Katlein, C.; Maslanik, J.; Hendricks, S. Changes in Arctic sea ice result in increasing light transmittance and absorption. Geophys. Res. Lett. 2012, 39. [CrossRef]

11. Zhuang, Y.; Jin, H.; Cai, W.-J.; Li, H.; Jin, M.; Qi, D.; Chen, J. Freshening leads to a three-decade trend of declining nutrients in the western Arctic Ocean. Environ. Res. Lett. 2021, 16, 054047. [CrossRef]

12. Zhang, M.; Marandino, C.A.; Yan, J.; Wu, Y.; Park, K.; Sun, H.; Gao, Z.; Xu, S. Unravelling Surface Seawater DMS Concentration and Sea-To-Air Flux Changes After Sea Ice Retreat in the Western Arctic Ocean. Glob. Biogeochem. Cycles 2021, 35. [CrossRef]

13. Terhaar, J.; Orr, J.C.; Ethé, C.; Regnier, P.; Bopp, L. Simulated Arctic Ocean Response to Doubling of Riverine Carbon and Nutrient Delivery. Glob. Biogeochem. Cycles 2019, 33, 1048-1070. [CrossRef]

14. Lewis, K.M.; van Dijken, G.L.; Arrigo, K.R. Changes in phytoplankton concentration now drive increased Arctic Ocean primary production. Science 2020, 369, 198-202. [CrossRef]

15. Zhuang, Y.; Jin, H.; Chen, J.; Li, H.; Ji, Z.; Bai, Y.; Zhang, T. Nutrient and phytoplankton dynamics driven by the Beaufort Gyre in the western Arctic Ocean during the period 2008-2014. Deep. Sea Res. Part I Oceanogr. Res. Pap. 2018, 137, 30-37. [CrossRef]

16. Bates, N.R.; Moran, B.; Hansell, D.; Mathis, J.T. An increasing CO2sink in the Arctic Ocean due to sea-ice loss. Geophys. Res. Lett. 2006, 33, 23609. [CrossRef]

17. Cai, W.-J.; Chen, L.; Chen, B.; Gao, Z.; Lee, S.H.; Chen, J.; Pierrot, D.; Sullivan, K.; Wang, Y.; Hu, X.; et al. Decrease in the CO 2 Uptake Capacity in an Ice-Free Arctic Ocean Basin. Science 2010, 329, 556-559. [CrossRef]

18. Chen, M.; Nam, S.-I.; Kim, J.-H.; Kwon, Y.-J.; Hong, S.; Jung, J.; Shin, K.-H.; Hur, J. High abundance of protein-like fluorescence in the Amerasian Basin of Arctic Ocean: Potential implication of a fall phytoplankton bloom. Sci. Total. Environ. 2017, 599-600, 355-363. [CrossRef]

19. DeFrancesco, C.; Guéguen, C. Long-term Trends in Dissolved Organic Matter Composition and Its Relation to Sea Ice in the Canada Basin, Arctic Ocean (2007-2017). J. Geophys. Res. Oceans 2021, 126, e2020JC016578. [CrossRef]

20. Shen, Y.; Benner, R.; Kaiser, K.; Fichot, C.; Whitledge, T.E. Pan-Arctic Distribution of Bioavailable Dissolved Organic Matter and Linkages with Productivity in Ocean Margins. Geophys. Res. Lett. 2018, 45, 1490-1498. [CrossRef]

21. Stedmon, C.; Markager, S.; Kaas, H. Optical Properties and Signatures of Chromophoric Dissolved Organic Matter (CDOM) in Danish Coastal Waters. Estuar. Coast. Shelf Sci. 2000, 51, 267-278. [CrossRef]

22. Guo, W.; Stedmon, C.; Han, Y.; Wu, F.; Yu, X.; Hu, M. The conservative and non-conservative behavior of chromophoric dissolved organic matter in Chinese estuarine waters. Mar. Chem. 2007, 107, 357-366. [CrossRef]

23. Yushmanova, A.; Kopelevich, O.; Vazyulya, S.; Sahling, I. Inter-Annual Variability of the Seawater Light Absorption in Surface Layer of the Northeastern Black Sea in Connection with Hydrometeorological Factors. J. Mar. Sci. Eng. 2019, 7, 326. [CrossRef]

24. Stedmon, C.A.; Markager, S. Tracing the production and degradation of autochthonous fractions of dissolved organic matter by fluorescence analysis. Limnol. Oceanogr. 2005, 50, 1415-1426. [CrossRef]

25. Guo, W.; Yang, L.; Hong, H.; Stedmon, C.; Wang, F.; Xu, J.; Xie, Y. Assessing the dynamics of chromophoric dissolved organic matter in a subtropical estuary using parallel factor analysis. Mar. Chem. 2011, 124, 125-133. [CrossRef]

26. Osburn, C.L.; Handsel, L.T.; Mikan, M.P.; Paerl, H.W.; Montgomery, M. Fluorescence Tracking of Dissolved and Particulate Organic Matter Quality in a River-Dominated Estuary. Environ. Sci. Technol. 2012, 46, 8628-8636. [CrossRef]

27. Markager, S.; Vincent, W.F. Spectral light attenuation and the absorption of UV and blue light in natural waters. Limnol. Oceanogr. 2000, 45, 642-650. [CrossRef]

28. Stedmon, C.A.; Bro, R. Characterizing dissolved organic matter fluorescence with parallel factor analysis: A tutorial. Limnol. Oceanogr. Meth. 2008, 6, 572-579. [CrossRef]

29. Coble, P.G.; Del Castillo, C.E.; Avril, B. Distribution and optical properties of CDOM in the Arabian Sea during the 1995 Southwest Monsoon. Deep Sea Res. Part II Top. Stud. Oceanogr. 1998, 45, 2195-2223. [CrossRef]

30. Jia, R.; Mu, X.; Chen, M.; Zhu, J.; Wang, B.; Li, X.; Astakhov, A.S.; Zheng, M.; Qiu, Y. Sources of particulate organic matter in the Chukchi and Siberian shelves: Clues from carbon and nitrogen isotopes. Acta Oceanol. Sin. 2020, 39, 96-108. [CrossRef]

31. Gueguen, C.; Guo, L.; Yamamoto-Kawai, M.; Tanaka, N. Colored dissolved organic matter dynamics across the shelf-basin interface in the western Arctic Ocean. J. Geophys. Res. Space Phys. 2007, 112. [CrossRef]

32. Shen, Y.; Fichot, C.G.; Benner, R. Dissolved organic matter composition and bioavailability reflect ecosystem productivity in the Western Arctic Ocean. Biogeosciences 2012, 9, 4993-5005. [CrossRef]

33. Guo, W.; Yang, L.; Zhai, W.; Chen, W.; Osburn, C.L.; Huang, X.; Li, Y. Runoff-mediated seasonal oscillation in the dynamics of dissolved organic matter in different branches of a large bifurcated estuary-The Changjiang Estuary. J. Geophys. Res. Biogeosci. 2014, 119, 776-793. [CrossRef]

34. Chen, M.; Huang, Y.; Guo, L.; Cai, P.; Yang, W.; Liu, G.; Qiu, Y. Biological productivity and carbon cycling in the Arctic Ocean. Chin. Sci. Bull. 2002, 47, 1037-1040. [CrossRef]

35. Zhuang, Y.; Jin, H.; Li, H.; Chen, J.; Lin, L.; Bai, Y.; Ji, Z.; Zhang, Y.; Gu, F. Pacific inflow control on phytoplankton community in the Eastern Chukchi Shelf during summer. Cont. Shelf Res. 2016, 129, 23-32. [CrossRef]

36. Anderson, L.G.; Amon, R.M. DOM in the Arctic Ocean. In Biogeochemistry of Marine Dissolved Organic Matter; Elsevier BV: Amsterdam, The Netherlands, 2015; pp. 609-633.

37. Zhuang, Y.; Jin, H.; Chen, J.; Ren, J.; Zhang, Y.; Lan, M.; Zhang, T.; He, J.; Tian, J. Phytoplankton Community Structure at Subsurface Chlorophyll Maxima on the Western Arctic Shelf: Patterns, Causes, and Ecological Importance. J. Geophys. Res. Biogeosci. 2020, 125, e2019JG005570. [CrossRef] 
38. Massi, L.; Frittitta, L.; Melillo, C.; Polonelli, F.; Bianchi, V.; De Biasi, A.M.; Nuccio, C. Seasonal Dynamic of CDOM in a Shelf Site of the South-Eastern Ligurian Sea (Western Mediterranean). J. Mar. Sci. Eng. 2020, 8, 703. [CrossRef]

39. Li, W.K.W.; McLaughlin, F.A.; Lovejoy, C.; Carmack, E.C. Smallest Algae Thrive as the Arctic Ocean Freshens. Science 2009, 326, 539. [CrossRef] [PubMed]

40. Zhuang, Y.; Jin, H.; Zhang, Y.; Li, H.; Zhang, T.; Li, Y.; Bai, Y.; Ren, J.; Chen, J. Incursion of Alaska Coastal Water as a mechanism promoting small phytoplankton in the western Arctic Ocean. Prog. Oceanogr. 2021, 197, 102639. [CrossRef]

41. Mathis, J.T.; Hansell, D.; Bates, N.R. Strong hydrographic controls on spatial and seasonal variability of dissolved organic carbon in the Chukchi Sea. Deep Sea Res. Part II Top. Stud. Oceanogr. 2005, 52, 3245-3258. [CrossRef]

42. Chen, M.; Jung, J.; Lee, Y.K.; Hur, J. Surface accumulation of low molecular weight dissolved organic matter in surface waters and horizontal off-shelf spreading of nutrients and humic-like fluorescence in the Chukchi Sea of the Arctic Ocean. Sci. Total. Environ. 2018, 639, 624-632. [CrossRef] [PubMed]

43. Brogi, S.R.; Ha, S.-Y.; Kim, K.; Derrien, M.; Lee, Y.K.; Hur, J. Optical and molecular characterization of dissolved organic matter (DOM) in the Arctic ice core and the underlying seawater (Cambridge Bay, Canada): Implication for increased autochthonous DOM during ice melting. Sci. Total. Environ. 2018, 627, 802-811. [CrossRef]

44. Stedmon, C.; Amon, R.; Rinehart, A.; Walker, S. The supply and characteristics of colored dissolved organic matter (CDOM) in the Arctic Ocean: Pan Arctic trends and differences. Mar. Chem. 2011, 124, 108-118. [CrossRef]

45. Zhuang, Y.; Li, H.; Jin, H.; Gao, S.; Chen, J.; Li, Y.; Bai, Y.; Ji, Z. Vertical distribution of nutrient tracers in the western Arctic Ocean and its relationship to water structure and biogeochemical processes. Acta Oceanol. Sin. 2020, 39, 109-114. [CrossRef]

46. Nishino, S.; Shimada, K.; Itoh, M. Use of ammonium and other nitrogen tracers to investigate the spreading of shelf waters in the western Arctic halocline. J. Geophys. Res. Oceans 2005, 110, e2019JC015428. [CrossRef]

47. Stedmon, C.A.; Amon, R.M.W.; Bauch, D.; Bracher, A.; Gonçalves-Araujo, R.; Hoppmann, M.; Krishfield, R.; Laney, S.; Rabe, B.; Reader, H.; et al. Insights into Water Mass Origins in the Central Arctic Ocean from In-Situ Dissolved Organic Matter Fluorescence. J. Geophys. Res. Oceans 2021, 126, e2021JC017407. [CrossRef] 